\title{
Undergraduates' Perception of (STEM) Education as a Tool for Enhancing Economic Development in Sokoto State, Nigeria
}

\author{
Dr. Suleiman Sa'adu Matazu
}

Department of Science and Vocational Education, Faculty of Education and Extension Services, Usmanu Danfodiyo University Sokoto, Nigeria

\section{ABSTRACT}

Article Info

Volume 8, Issue 4

Page Number : $162-170$

\section{Publication Issue :}

July-August-2021

\section{Article History}

Accepted : 15 July 2021

Published: 20 July2021
Economic development appears to be a major challenge confronting nations and individuals across the globe in recent times. Economic development is the process by which a nation improves the economic, political, and social well-being of its people. Nigeria which is tagged as the giant of Africa, and also endowed with numerous natural and human resources, is still battling with the menace of economic under development particularly Sokoto state. This paper therefore, examined the perception of undergraduates on (STEM) education as a tool for enhancing economic development. The study employed a quantitative research design, with a sample of 200 undergraduate students of Usmanu Danfodiyo University, Sokoto (UDUS). The sampled students were randomly selected from four programs of study. A questionnaire containing (12) items, entitled Perception of Undergraduates on STEM for Enhancing Economic Development (PUSEEED) was utilized in collecting data for the study. The instrument was content validated by 3 experts. The reliability index of 0.82 was calculated for the instrument using the Cronbach Alpha. The result of the study indicated that the undergraduates appreciated the introduction of STEM education as a tool for enhancing economic development and they looked forward to actively participating in the program once it is practically integrated into their programs. It was recommended among others that STEM education should be incorporated into the entrepreneurial programs of Nigerian universities especially in Sokoto state, Nigeria for meaningful economic development.

Keywords: Economic Development, Sokoto, STEM, Undergraduates

\section{INTRODUCTION}

Science, Technology, Engineering and Mathematics (STEM) education is based on the notion of enlightening students in the four disciplines of Science [1]. It is an educating package established to prepare primary, secondary, college and university students in the field of Science, Technology, Engineering and Mathematics. In addition to specific subject learning, STEM aims at fostering inquiry minds, logical reasoning, problem solving skills, cultivate higher order thinking skills as well as 
collaborative skills [2], [3], [4]. STEM Education is more than just demonstration and propagation of information and cultivation of practices, but it's a route of teaching and learning that offers students the openings to make sense of the world and take charge of their learning rather than learning isolated bits and pieces of content in science [5]. In the STEM environment, there is less emphasis on activities that demonstrate science content and greater focus on those activities that allows students to engage in the real-world problems and experiences through projectbased, experiential learning activities that lead to higher level thinking. Learning in a STEM surroundings compels students to understand issues, distil problems, and comprehend processes that lead to innovative solutions [6]. Nigeria like other nations in the world, is increasingly reliant on the Science, Technology, Engineering and Mathematics (STEM) to attain position in the world economy.

STEM Education Literarily means the act of imparting scientific, technological, engineering and mathematical knowledge, competencies and skills for personal survival and overall development of the nation [6]. However, STEM learning has the prospect to produce competitive future workforce with the 21st century skills [7] and in turns positively make an impact towards students' interest [8], [4].

Nigerian government seek solution to the issue of economic development and self-sufficiency within the broad context maximizing the potentials of STEM Education.

The overall objectives of Science, Technology, Engineering and Mathematics Education at the basic level aim at providing knowledge, skills and capacity building for self-reliance. These goals as stated in Nigerian National Policy on Education include

$\checkmark$ Develop the intellectual capability of individuals to understand and appreciate their local and external environment $\checkmark$ Acquire both physical and intellectual skills which will enable individual to be self-reliant and useful member of the society

$\checkmark$ Contribute to national development through high level and relevant manpower training.

More so, when STEM students are provided with knowledge, positive attitude and skills through quality basic and higher STEM education, the learners become intellectually empowered and technologically driven to create the right environment for revenue generation and manage effectively the available resources for economic development.

Beautiful as these pronunciations could be, the practice of STEM education in Nigeria is not so, confronted with a lot of issues surrounding policies implementation, attitude and managerial issues.

Global development in STEM showed that access to basic education continues to dominate argument world over and that increasing Science, Technology, Engineering and Mathematics knowledge is part of this basic education. Under the UN Human Rights Charter, the correlation between the numbers of STEM related research personnel and the affluence of a nation is well established [9]. It is important therefore to note that global developments in respects to STEM Education required countries to have well trained and well-motivated STEM teachers, adequate supply of relevant equipment and facilities for effective teaching and learning of STEM including ICT facilities, learner friendly teaching and learning environment, encouragement for positive attitude to STEM Education by all and finally development of scientific culture among other things [10]. These of course are the happenings globally in respect to STEM Education. 


\section{PROBLEM STATEMENT}

An instant concern exists in the Nigeria educational system over the lack of skilled workers in science, technology, engineering, and mathematics (STEM) [10]. However, numerous problems, such as implementation issues, are risen because of a lack of teacher training in STEM as an integrated curriculum [11]. In response to the STEM crisis, [12] argued that individual wealth and wealth of a nation is no longer a function of its natural resources' endearments, but the strength and worth of its labor force. This implies that capacity building to produce quality human resources who will turn out as future planners and managers of nation's economy can be achieved through effective teaching and learning of (STEM) education. It would therefore be right to say of (STEM) Education has a crucial role to play in empowering and sustaining skills that will foster economic development. It also means that different levels of education especially secondary and tertiary institutions, as a matter of absolute necessity, have to equip the learners with appropriate and sustained knowledge, skills and competencies to manage available resources as well as generate revenue [13].

It's important to note that, individuals and nations can grow economically if skills and potentials of (STEM) Education can be properly harnessed and integrated for economic development of individuals and nations. Ref [12] opined that science education is a key driver of economic development of any nation and maintained that the ability to harness the potentialities of (STEM) Education is a major source of competitive advantage, wealth generation and improvement in quality of life. Despite, the importance of STEM education in teaching and learning, Nigeria situation is still backward in fully integrating STEM education in its educational system [10].
Researches on STEM education such as those by [14; $15 ; 16]$ have been conducted though, there is a limited number of researches focusing specifically on integrating STEM as a tool for enhancing economic development. In respective of numerous efforts applied to reinforce STEM education, there are major challenges faced by teachers and educators to find suitable approaches to fully implement STEM education in Nigeria. This paper therefore, attempted to determine the perception of undergraduate students on STEM education as a tool for economic development.

\section{RESEARCH AREA}

This research was conducted in Sokoto state. Sokoto state is located in the extreme North-West of Nigeria, located immediate to the confluence of the Sokoto River and the Rima River. The state has 23 local government area. There are two major indigenous tribes in the state, which are the Hausa and Fulani and others include Gobirawa, Zabarmawa, Kabawa, Yorubas, Igbos and others. A large number of the Hausas' are farmers while Fulani's are nomadic cattle rearers (Sokoto state diary of the ministry of education, 2008). The state had approximately population of $3,696,999$, as at 2006 census.

\section{OBJECTIVE OF THE RESEARCH}

The main objective of the study was to determine the perception of undergraduate students on STEM in enhancing economic development in Sokoto state, Nigeria

\section{RESEARCH QUESTIONS}

The central question of this research revolves around the perception of undergraduate students of STEM education for enhancing economic development resulting into the following specific questions as follows; 
1. What is the perception of undergraduate on STEM education for enhancing economic development based on their gender?

2. What is the perception of undergraduate on STEM education for enhancing economic development based on program on study?

3. What is the perception of undergraduate on STEM education for enhancing economic development based on level of study?

\section{RESEARCH HYPOTHESES}

The following null hypotheses were raised and tested in this study:

Ho1: There is no significant difference in the mean perception of undergraduate on STEM education for enhancing economic development based on gender.

Ho2: There is no significant difference in the mean perception of undergraduate on STEM education for enhancing economic development based on program on study.

Ho3 There is no significant difference in the mean perception of undergraduate on STEM education for enhancing economic development based on level of study.

\section{METHODOLOGY}

This study was a survey, the populations for the study comprised of all undergraduate students of Usmanu Danfodiyo University, Sokoto (UDUS). A sample of 200 respondents were utilized as participants in the study. Purposive sampling was adopted in choosing respondents' program of study (Mathematics, Engineering, Biology and Chemistry). While simple random sampling was employed to choose the number of participants from each program of study.

The research instrument was a self-designed questionnaire by the researcher, entitled "Perception of Undergraduate on STEM Education for Enhancing Economic Development (PUSEEED) the questionnaire containing 12 items was designed to elicit information from the undergraduate's students on their perception of STEM education for enhancing economic development. All questions were constructed on a 4-point Likert - type scale as: strongly agree $=\mathrm{SA}$, agree $=\mathrm{A}$, disagree $=\mathrm{D}$ and strongly disagree $=\mathrm{SD}$. The instrument was given to Subject Matter Experts (SME) to determine its content validity. The result was calculated using the [17] formula for content validity ratio. Based on the experts' comments the instrument was modified. The instrument's reliability was calculated using Cronbach Alpha and a reliability index of 0.82 was obtained, and was considered reliable enough for use in the current study. The data collected was entered into SPSS version 22, after which descriptive and inferential statistics were employed for the analysis of the collected data.

\section{RESULT}

The research study presents the characteristic of the respondents of the study based on their gender, program of study and the levels of study for a concise picture of the respondents of the study.

TABLE 1

DEMOGRAPHIC CHARACTERISTIC BASED ON GENDER

\begin{tabular}{|l|l|l|}
\hline Gender & Frequency & $\begin{array}{c}\text { Percentage } \\
\%\end{array}$ \\
\hline Males & 124 & 62.0 \\
\hline Females & 76 & 38.0 \\
\hline
\end{tabular}

Table 1 revealed that $124(62.0 \%)$ of the respondents were males and 76 (38.0\%) were females. This simply implies that more male students participated in the study than females. This may be as a result of the fact that there are more males studying science courses than females in the study area (UDUS).

TABLE 2 
DISTRIBUTION OF RESPONDENTS BASED ON LEVEL OF STUDY

\begin{tabular}{|l|c|c|}
\hline Level of Study & Frequency & $\begin{array}{c}\text { Percentage } \\
\text { (\%) }\end{array}$ \\
\hline 100 Level & 111 & 55.5 \\
\hline 200 Level & 46 & 23 \\
\hline 300 Level & 14 & 7 \\
\hline 400 Level & 21 & 10.5 \\
\hline 500 Level & 8 & 4 \\
\hline
\end{tabular}

Table 2 unveiled that 111 (55.5\%) were in their first year of study, $46(23 \%)$ were in their second year of study, $14(7 \%)$ were in their third year of study, 21 $(10.5 \%)$ were in their fourth year of study while 8 (4\%) were in their fifth year of study.

\section{TABLE 3}

RESPONDENTS DISTRIBUTION BASED ON PROGRAM OF STUDY

\begin{tabular}{|l|c|c|}
\hline $\begin{array}{l}\text { Program of } \\
\text { Study }\end{array}$ & Frequency & $\begin{array}{c}\text { Percentage } \\
\text { (\%) }\end{array}$ \\
\hline Engineering & 43 & 21.5 \\
\hline Mathematics & 37 & 18.5 \\
\hline Biology & 59 & 29.5 \\
\hline Chemistry & 61 & 30.5 \\
\hline
\end{tabular}

Table 3 showed that 43 (21.5\%) of the respondents were Engineering students, 37 (18.5\%) were Mathematics students, 59 (29.5\%) were Biology students and 61 (30.5\%) were in Chemistry.

\section{TABLE 4}

MEAN, STD. DEV. AND RANK OF RESPONDENTS PERCEPTION

\begin{tabular}{|l|c|c|c|c|}
\hline Item & N & Rank & Mean & $\begin{array}{c}\text { Std. } \\
\text { Dev. }\end{array}$ \\
\hline $\begin{array}{l}\text { A STEM based } \\
\text { curriculum in schools } \\
\text { would enable } \\
\text { individual study more } \\
\text { of science }\end{array}$ & 200 & 2 & 4.63 & .60 \\
\hline Having STEM & 200 & 4 & 4.24 & .76 \\
\hline
\end{tabular}

\begin{tabular}{|c|c|c|c|c|}
\hline $\begin{array}{l}\text { integrated in } \\
\text { educational system } \\
\text { will bring better } \\
\text { development in the } \\
\text { country }\end{array}$ & & & & \\
\hline $\begin{array}{l}\text { STEM makes a } \\
\text { meaningful difference } \\
\text { in the world }\end{array}$ & 200 & 8 & 4.13 & .71 \\
\hline $\begin{array}{l}\text { My family is } \\
\text { interested in my } \\
\text { studying a STEM } \\
\text { related course }\end{array}$ & 200 & 10 & 3.96 & .94 \\
\hline $\begin{array}{l}\text { I would like to have a } \\
\text { career in STEM }\end{array}$ & 200 & 5 & 4.21 & .79 \\
\hline $\begin{array}{l}\text { I am a supporter of } \\
\text { the implementation of } \\
\text { STEM in the } \\
\text { Curriculum of } \\
\text { education }\end{array}$ & 200 & 9 & 4.12 & .91 \\
\hline $\begin{array}{l}\text { My family encouraged } \\
\text { me to study STEM } \\
\text { related course }\end{array}$ & 200 & 12 & 3.76 & .95 \\
\hline $\begin{array}{l}\text { I would enjoy a career } \\
\text { in STEM }\end{array}$ & 200 & 11 & 3.82 & .98 \\
\hline $\begin{array}{l}\text { STEM is a catalyst in } \\
\text { the enhancement of a } \\
\text { nations economic } \\
\text { development }\end{array}$ & 200 & 7 & 4.15 & .88 \\
\hline $\begin{array}{l}\text { I will make an impact } \\
\text { in the society when I } \\
\text { graduate from } \\
\text { studying in STEM } \\
\text { related course }\end{array}$ & 200 & 3 & 4.33 & .64 \\
\hline $\begin{array}{l}\text { I will have a } \\
\text { successful professional } \\
\text { career to contribute } \\
\text { my quota to the } \\
\text { economic } \\
\text { development through } \\
\text { STEM }\end{array}$ & 200 & 6 & 4.19 & .83 \\
\hline Having STEM fully & 200 & 1 & 5.06 & .52 \\
\hline
\end{tabular}




\begin{tabular}{|lr|l|l|l|}
\hline integrated in & & & & \\
educational system & & & & \\
will bring better & & & & \\
development in the & & & & \\
country & & & & \\
\hline
\end{tabular}

Table 4 revealed that the undergraduate students perceived that having STEM fully integrated in the educational system will bring a better development in the country ranking highest on their perception on STEM for enhancing economic development. This gives us the general answer to what the perception of undergraduates is on STEM education for enhancing economic development.

Ho1: There is no significant difference in the mean perception of undergraduate on STEM education for enhancing economic development based on gender.

\section{TABLE 5}

T-STATISTICS ON DIFFERENCE OF PERCEPTION OF UNDERGRADUATE STUDENTS ON STEM BASED ON GENDER

\begin{tabular}{|l|c|c|c|c|c|c|c|}
\hline $\begin{array}{c}\text { Grou } \\
\mathbf{p}\end{array}$ & $\mathbf{N}$ & $\begin{array}{c}\text { Mea } \\
\mathbf{n}\end{array}$ & Std & df & T & P & $\begin{array}{c}\text { Remar } \\
\mathbf{k s}\end{array}$ \\
\hline Male & 12 & 40.8 & 11.5 & 19 & 0.98 & $>$ & Accept \\
Femal & 4 & 7 & 9 & 8 & 6 & 0.0 & \\
e & 76 & 39.2 & 10.6 & & & 5 & \\
& & 2 & 7 & & & & \\
\hline
\end{tabular}

The result in table 5 showed that there exist no significant differences in the undergraduate perception on STEM education for enhancing economic development based on their gender. $\mathrm{P}$ value (0.32) > alpha value (0.05), while calculated T-value $0.986<$ critical table value 1.96 . Thus, null hypothesis accepted. This implies that gender has nothing to do with undergraduates' perception of STEM education for economic development.

Ho2: There is no significant difference in the mean perception of undergraduate on STEM education for enhancing economic development based on program on study.

TABLE 6

ANALYSIS OF VARIANCE OF PERCEPTION OF UNDERGRADUATE STUDENTS ON STEM BASED ON THEIR PROGRAM OF STUDY

\begin{tabular}{|l|c|c|c|c|c|}
\hline $\begin{array}{l}\text { Source } \\
\text { of } \\
\text { Varianc }\end{array}$ & $\begin{array}{c}\text { Sum of } \\
\text { Squares }\end{array}$ & Df & MS & F & $\begin{array}{c}\text { Remark } \\
\text { e }\end{array}$ \\
\hline Between & 7623 & 2 & 3933.5 & & Accept \\
Group & 1520275. & 19 & 4612.4 & 0.9 & \\
Within & 6 & 7 & 8 & 7 & \\
Group & 1527898. & 19 & & & \\
Total & 6 & 9 & & & \\
\hline
\end{tabular}

Table 6 above presents the result of analysis of variance employed to test the significant difference in the perception of undergraduate students on STEM education for economic development based on their program of study. It showed that, an F value of 0.97 was obtained which was less than a critical value of 3.02 at $\mathrm{p}<0.05$. This implies that, there was no significant difference in perception of undergraduate students of (UDUS) on STEM education for economic development in Sokoto state. The hypothesis tested was therefore retained.

Ho3: There is no significant difference in the mean perception of undergraduate on STEM education for enhancing economic development based on level of study. 
TABLE 7

ANALYSIS OF VARIANCE OF PERCEPTION OF UNDERGRADUATE STUDENTS ON STEM BASED ON THEIR LEVEL OF STUDY

\begin{tabular}{|l|c|c|c|c|c|}
\hline $\begin{array}{l}\text { Source } \\
\text { of } \\
\text { Variance }\end{array}$ & $\begin{array}{c}\text { Sum of } \\
\text { Squares }\end{array}$ & Df & MS & F & Remarks \\
\hline $\begin{array}{l}\text { Between } \\
\text { Group }\end{array}$ & 9.276 & 2 & 4.433 & & $\begin{array}{c}\text { Not } \\
\text { Accepted }\end{array}$ \\
$\begin{array}{l}\text { Within } \\
\text { Group } \\
\text { Total }\end{array}$ & 152.643 & 197 & 0.673 & 6.64 & \\
\hline
\end{tabular}

The results of the analysis in table 7 indicated a significant difference has been found in the perception of undergraduate students on STEM education for economic development in reference to their level of study $(\mathrm{F}=6.64, \mathrm{p}<.05)$.

\section{DISCUSSION OF FINDINGS}

The study is a survey on the perception of undergraduate students on STEM for enhancing economic development in UDUS Sokoto state, Nigeria. Emanating from the results of this study is that the undergraduate students of UDUS have a high expectation of the integration of STEM into the educational system which they believe it will bring about economic development in the nation. The students submitted that integration of STEM will also lead to active learning engagement, ability to enhance critical thinking through the exploration of realworld situations and developing the solutions upon project completion. The findings of this study indicated that, male and female students have no difference in their perception of STEM education for enhancing economic development. Thus, confirming and supporting the findings of [3] and the findings in study carried out by [18] which unveil that the differences in the mean scores for Items 1, 2, 3, 5, 6, 7,
8 and 10 were not statistically significant between male and female students at the significance level of .05, implying there were no statistically significant differences in the perceptions of assessments in STEM related subjects as measured by these items between sex of students. But in contrast with the study of [6] who investigated Student perceptions of Science, Technology, Engineering and Mathematics (STEM) content and careers and the outcome showed that female outperformed their male counterpart, it is also in line with the work of [19].

Furthermore, the study also found that program of study does not differentiate undergraduate perception on STEM education for economic development. This is in line with the findings of [18] in which the results also indicated that there was significant difference in the overall perceptions of assessments in STEM related subjects in terms of school category at the significance level of .05

Lastly the study unveils that the perceptions of undergraduate on STEM and their level of study has a significant difference, this is in line with the work of [20] whom discovered differences in the students' career plans of STEM students. This is also in line with the study [21] where they discovered that there were statistically significant differences in the perceptions of assessments in STEM related subjects between Daily Normal School and Full Boarding High-Performing School students, favouring the Full Boarding High-Performing School. This also goes same as the findings of [18] that discovered teachers in different STEM disciplines have varied perceptions about STEM integration which leads to different classroom practices.

\section{CONCLUSION}

Conclusively, data gathered from 200 undergraduate students of Usmanu Danfodiyo University, Sokoto (UDUS) was used to expose the perceptions of 
undergraduate students on STEM education for enhancing economic development. As stated earlier, full integration of STEM education should be emphasized accurately. Thus, educators and teachers will have the guidance in planning the teaching process of STEM subjects. However, researches on these areas should dig deeper to provide a greater understanding to teachers and educators. In Nigeria, more local study should be conducted on the impact of full integration of STEM education from primary to university level. It is therefore, recommended that STEM education should be incorporated into the entrepreneurial programs of Nigerian universities especially in Sokoto state, Nigeria.

\section{REFERENCES}

[1]. A. H Elaine, Connecting Girls and Science: Constructivism, Feminism and Education Reform. New York: Teachers College Press 2002.

[2]. M. Stohlmann and T. J. Moore, Consideration for Teaching Integrated STEM Education. Journal of Pre-college Engineering Education Research 2012.

[3]. M. Sanders, Integrative STEM Education as "best practice" Paper presented at the seventh Biennial International Technology Education Research Conference, Queensland Australia 2012.

[4]. M. Norazla, Z. Ismai, Z. Tasir, and M. N. H. Mohamad Said A Meta-Analysis on Effective Strategies for Integrated STEM Education. Advanced Science Letters Vol. 12. Pp 4225- 4229. DOI:10.1166/asl.2016.8111 2016.

[5]. M. C. Ndirikia, and P. C Agommuoh, Enhancing Female Participation in STEM Education towards Sustainable, Inclusive and Equitable Development. 60th Anniversary Conference Proceedings of STAN 2017.

[6]. Rouse, M. and Gibiliscon, S. Science, Technology, Engineering and Mathematics Education. Retrieved from
http://whatis.techtarget.com/defination/STEMJanuary, 14, 2017.

[7]. X. S. Apedoe, B. Reynolds, M. R. Ellefson, and C. D. Schunn, Bringing Engineering Design into High School Science Classroom: The Heating/ Cooling unit. Journal of Science Education and Technology, 17(5), 454-465, 2008.

[8]. H. Wang, T. Moore, G. H. Roehrig, and M. S. Park, "STEM Integration: Teacher Perceptions and Practice," Journal of Pre-College Engineering Education Research (J-PEER): Vol. (1): Iss.(2), Article2. https://doi.org/10.5703/1288284314636. 2011.

[9]. K. Shaikh, UNESCO International Science, Technology and Environmental Education: Newsletter, xxv, 3-4. 2000.

[10].B. J. Obomanu, and M. O. Adaramola, Factors Related to Under Achievement in Science, Technology and Mathematics Education (STME) in Secondary Schools in Rivers State, Nigeria. World Journal of Education. Vol. 1, No. 1. Pp 102-109. doi:10.5430/wje.v1n1p102. 2011.

[11].H. Gonzales, and J. Kuenzi, Science, technology, engineering, and mathematics (STEM) education: A primer (Report R42642). Retrieved from the Congressional. 2012.

[12].B. B. Akpan, Nigeria and the Future of Science Education. Science Teachers Association of Nigeria. 2008.

[13].N. Udofia, Creating Science within and beyond the Classroom: Strategies for African Learners. World Conference on Science and Technology Education. Sarawak, Borneo, Malaysia 29 September - 3 October 2013. 2013.

[14].J. Smith, and P. Karr-Kidwell, The Interdisciplinary Curriculum: a literary review and a manual for administrators and teachers. Retrieved from ERIC database. (ED443172). 2000.

[15].Fortus, D. Krajcikb, J. Dershimerb, R. C. Marx R. W. and Mamlo-Naamand, R. (2005). Design-base Science and Real-world Problem Solving. 
International Journal of Science Education, 855879.

[16].J. G. Wells, and J. V. Ernst, Integrated STEM Education. Virginia Technical School Education. 2011.

[17].C. H. Lawshe, (1975) A quantitative approach to content validity. Personnel Psychology, 28, pp. 563-575. 2012.

[18].C. C. Meng, N. Idris, and L. K. Eu, Secondary Students' Perceptions of Assessments in Science, Technology, Engineering, and Mathematics (STEM). Eurasia Journal of Mathematics, Science \& Technology Education, 10(3), 219-227. 2014.

[19].J. Navarra-Madsena, R. A. Balesb, and D. L. Hynds, Role of Scholarships in Improving Success Rates of Undergraduate Science, Technology, Engineering and Mathematics (STEM) Majors. Procedia Social and Behavioral Sciences 8 , 458-464. doi:10.1016/j.sbspro.2010.12.063. 2010.

[20].J. Sikora, and A. Pokropek, Gender Segregation of Adoloscent Science Career Plans in 50 Countries. Science Education. 96(2), 234-264. 2012.

[21].R. Chritensen, G. Knezek, and T. Tyler-Wood, Students Perception of Science, Technology, Engineering and Mathematics (STEM) Content and Career. Computer in Human Behaviour 34, Pp173-186. 2014.
Dr. Suleiman Saadu Matazu, "Undergraduates' Perception of (STEM) Education as a Tool for Enhancing Economic Development in Sokoto State, Nigeria", International Journal of Scientific Research in Science, Engineering and Technology (IJSRSET), Online ISSN : 2394-4099, Print ISSN : 2395-1990, Volume 8 Issue 4, pp. 162-170, July-August 2021. Available at doi : https://doi.org/10.32628/IJSRSET218431 Journal URL : https://ijsrset.com/IJSRSET218431

\section{Cite this article as :}

